\title{
Molecular identification of Gracilaria species (Gracilariales, Rhodophyta) obtained from the South Coast of Java Island, Indonesia
}

\author{
MARIA DYAH NUR MEINITA ${ }^{1,2, \boldsymbol{v}}$, NASHIATUL AKROMAH ${ }^{1}$, NURAINA ANDRIYANI ${ }^{1}$, SETIJANTO $^{1}$, \\ DICKY HARWANTO ${ }^{3}$, TAO LIU ${ }^{4}$. \\ ${ }^{1}$ Faculty of Fisheries and Marine Science, Universitas Jenderal Soedirman. J1. Dr. Soeparno, Purwokerto Utara, Banyumas 53122, Central Java, \\ Indonesia. Tel./fax.: +62-281-642360, `email: maria.meinita@unsoed.ac.id. \\ ${ }^{2}$ Center for Maritime Bioscience Studies, Institute of Research and Community Service, Universitas Jenderal Soedirman. Jl. Dr. Soeparno, Purwokerto \\ Utara, Banyumas 53122, Central Java, Indonesia \\ ${ }^{3}$ Faculty of Fisheries and Marine Science, Universitas Diponegoro. J1. Prof. Soedarto, SH, Tembalang, Semarang 50275, Central Java, Indonesia \\ ${ }^{4}$ College of Marine Life Sciences, Ocean University of China. Qingdao 266100, China
}

Manuscript received: 24 December 2020. Revision accepted: 30 June 2021.

\begin{abstract}
Meinita MDN, Akromah N, Andriyani N, Setijanto, Harwanto D, Liu T. 2021. Molecular identification of Gracilaria species (Gracilariales, Rhodophyta) obtained from the South Coast of Java Island, Indonesia. Biodiversitas 22: 3046-3056. The study of seaweeds diversity and species identification is an important component of marine resource management. However, seaweed identification based on morphological characteristics has several limitations. Besides, DNA barcodes or the partial sequences of cytochrome c oxidase I (COX1) have been proved to identify seaweeds at the species level. To date, Gracilaria species molecular diversity has not been studied in the South Coast of Java Island. Hence, this study aimed to identify the Gracilaria spp. obtained from 6 different beaches along the South Coast of Java, based on the COX1 gene. COX1 gene utilization for identifying and observing the genetic diversity, both intraspecific (genetic variation within species) and interspecific (variations between species) of Gracilaria species in this study has produced good results. A total of 13 seaweed samples collected from beaches in this study were identified as Gracilaria salicornia, G. edulis, G. firma, and G. textorii. The results of genetic diversity analysis conducted using the COX1 gene showed the intraspecific diversity of G. edulis obtained from the beaches of Kondang Merak, Kukup, Nusakambangan, and Karapyak was included in the moderate diversity category. Also, the intraspecific diversity of G. salicornia obtained from the beaches of Kondang Merak, Kukup, and Nusakambangan was included in the moderate diversity category, while the intraspecific diversity of $G$. textorii from Menganti and Karapyak Beach had no diversity.
\end{abstract}

Keywords: Barcode, COX1, Gracilaria, molecular, seaweeds

\section{INTRODUCTION}

Tropical sea exhibits high biodiversity providing a favorable habitat for many marine creatures, including seaweeds. As the largest archipelago country, Indonesia is a representative to describe the tropical biodiversity and is the second seaweed producer globally (FAO 2020). About 555 seaweed species are recorded in Indonesia, from which 55 have high economic value, belonging to the genera Eucheuma (J. Agardh), Gracilaria (Greville), and Gelidium (J. V. Lamouroux 1813) (Kadi 2004). Species of the genus Gracilaria are distributed from intertidal to subtidal habitats, occurring in most oceans. Their distribution spread from temperate to tropical waters, including Southeast Asian regions (Kim et al. 2010; Heo et al. 2011; Kongkittayapun and Chirapart 2011; Yang and Kim 2015). Members of the red algal family Gracilariaceae are highquality raw material sources in the food-grade agar industry. Agar is widely used as a hydrocolloid in various industrial fields, especially in food, pharmaceuticals, cosmetics, and bioenergy (de Almeida et al. 2011; Meinita et al. 2017; Torres et al. 2019). Globally, agar production exceeds 14,500 tons annually (Porse and Rudolph 2017). Moreover, the increasing demand for seaweeds in food, cosmetics, and pharmaceutical industries has begun since
1980 (Bixler and Porse 2011; Porse and Rudolph 2017). As technology develops, the demand for agar raw materials also increases. Gracilaria spp. continuous utilization causes population decline and limited availability in nature, hence managing their biodiversity is necessary. Besides, biodiversity is an important aspect of resource management efforts related to long-term sustainable use (Nesbitt et al. 2010).

Indonesia is one of the largest producers of farmed Gracilaria, specially Gracilariopsis longissimi and $G$. gigas (Pambudi et al. 2010; Meinita et al. 2018). Unfortunately, there has not been a comprehensive study on Indonesian seaweed after Siboga and Snellius expedition. Most seaweed diversity studies in Indonesia were done partially in a certain area. Indonesian seaweed diversity is hard to be precisely reported as a part of other works or publications made several decades after the expedition. Its first published records were due to the expeditions in 1899 undertaken by Weber-van Bosse which discovered 782 seaweeds, consisting of 179 green algae, 134 brown algae, and 452 red algae (Hutomo and Moosa 2005). During the Snellius-II Expedition in 1984, herbarium species of marine alga was also collected from the Eastern part of the Indonesian Archipelago. 
The study sites selected were the beaches of Kondang Merak, Kukup, Menganti, Nusakambangan, Karapyak, and Sayang Heulang which lie along the South Coast of Java Island and directly adjacent to the Indian Ocean. Moreover, the South Coast of Java Island has extreme conditions with steep topographic characteristics and strong waves, while the location also affects the Gracilaria spp diversity.

Seaweeds morphology changes due to unstable environmental conditions (Kongkittayapun and Chirapart 2011). However, Indonesian Gracilaria spp. Identification is commonly based on morphological features. This process has some limitations that lead to the species misidentification due to their high phenotypic plasticity (Hassan et al. 2019). Correct identification is crucial for biodiversity studies, while misidentification influences the faults in determining biodiversity. Molecular identification based on genetic information using DNA sequences has more accuracy than morphological identification. Therefore, it is necessary because of being capable to provide more accurate information on a species genetic diversity. Some molecular studies of Gracilariaceae have been conducted (Liu et al. 2017; Sedanza et al. 2020; Wang et al. 2020), but not in Indonesia. A molecular study of this country's Gracilaria species was conducted using RAPD marker (Windarsih et al. 2019) to characterize their genetic profile with random single oligonucleotides, however, the RAPD also has limitations due to its low reproducibility.

COX1 (cytochrome c oxidase subunit 1) is one of the genes in mitochondrial DNA used to determine Gracilaria spp. genetic diversity. According to Sherwood et al. 2011, the COX1 gene is used to determine red seaweed species genetic diversity and the population's biogeographic structure. Several studies on Gracilaria spp. genetic diversity based on COX1 genes that have been carried out includes G. firma, G. vermiculophylla, G. salicornia, and G. changii (Yang et al. 2008; Yow et al. 2011; Gulbransen et al. 2012; $\mathrm{Ng}$ et al. 2017; Hifney et al. 2018; Song et al. 2019). The southern part of Java Island is known as a tropical area with a high seaweed diversity (Romdoni et al. 2018). Hence, this study investigated the natural seaweed potential along the aforementioned area.

\section{MATERIALS AND METHODS}

\section{Study area}

According to Figure 1, seaweed species were collected

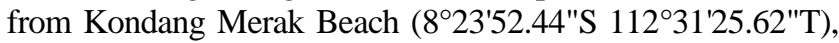
Kukup Beach ( $\left.8^{\circ} 06^{\prime} 48.68^{\prime \prime S} 110^{\circ} 34^{\prime} 44.41^{\prime \prime T}\right)$, Menganti Beach, Nusakambangan Beach (745'15.29"S 10901'04.68"T), Karapyak Beach (742'9.86"S 108 45'38.28"T) and Sayang Heulang Beach $\left(7^{\circ} 38^{\prime} 16.34^{\prime \prime S} 107^{\circ} 41^{\prime} 50.30^{\prime \prime T}\right)$. These locations were selected to represent the coastal area in the Southern part of Java Island. Besides, samples were cleaned off dirt, sand, and periphyton, then washed with sterile seawater, stored in clean plastic, and coded, followed by storage in a freezer at $-20^{\circ} \mathrm{C}$ for further analysis.

\section{Morphological identification}

Morphological identification that involved DNA isolation and sequencing method was performed using the key of determination, based on the type and tip of thallus, and branching type.

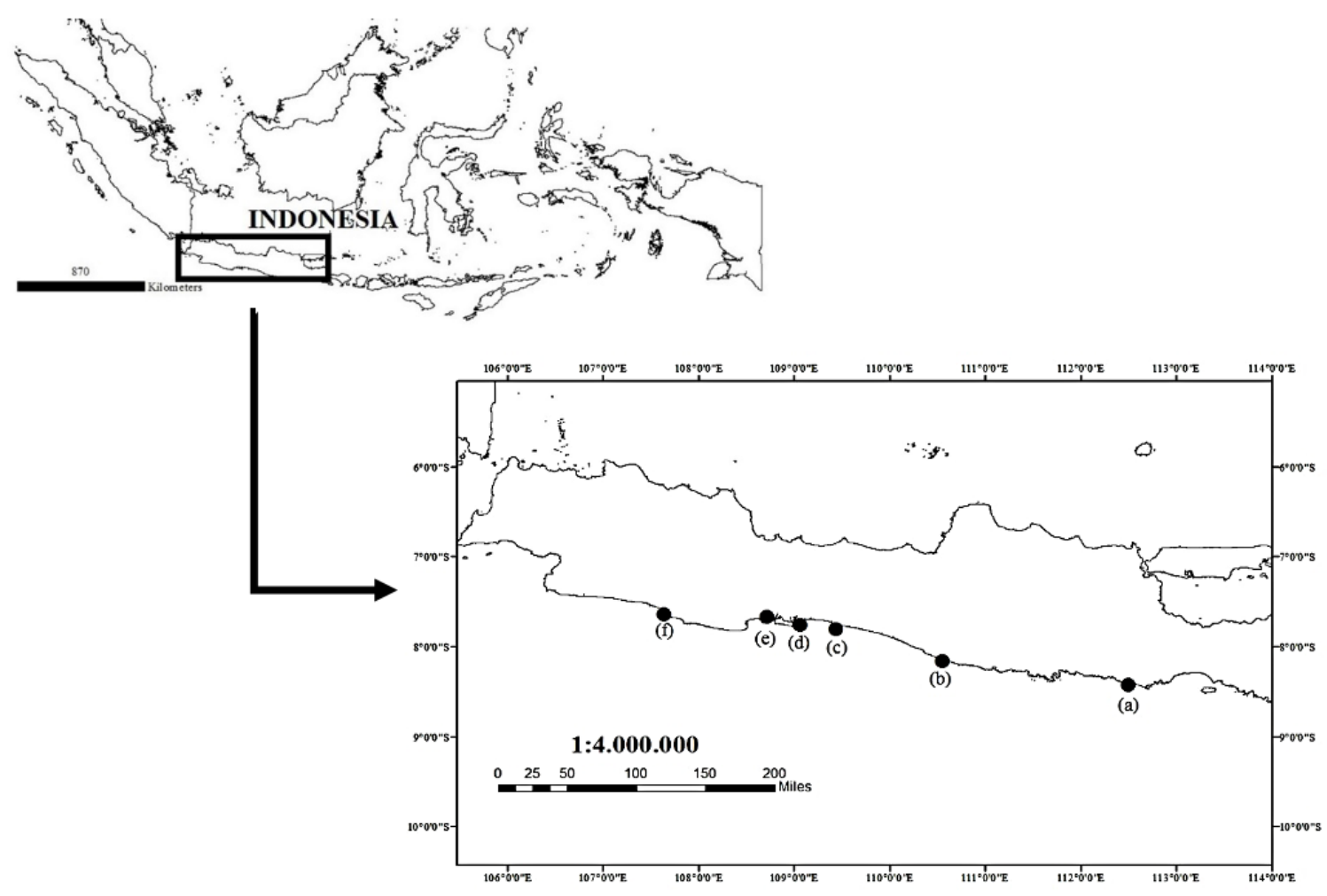

Figure 1. Location of the six beaches along the South Coast of Java Island, Indonesia: A. Kondang Merak, B. Kukup, C. Menganti, D. Nusakambangan, E. Karapyak, and F. Sayang Heulang 


\section{DNA isolation and sequencing}

DNA was extracted from approximately $4 \mathrm{mg}$ of algal powder ground in liquid nitrogen using the CTAB (Cetyl Trimethyl Ammonium Bromide) method. This isolate was then tested for quantity using spectrophotometers at 260 $\mathrm{nm}$ and $280 \mathrm{~nm}$, to determine DNA purity and concentration. The purity was observed through A260:A280 ratio by agarose gel electrophoresis. However, quality analysis was carried out by agarose gel electrophoresis method, to determine DNA presence, integrity, and purity level from RNA contaminants. The DNA isolate was then amplified through the polymerase chain reaction (PCR) process, using COX1 primers, namely COX143F and COX11549R (Geraldino et al. 2006). The mitochondrial COX1 sequences were aligned and used to devise specific primers to amplify this gene region for Gracilaria (upstream COXI43F-5, TCA ACA AAT CAT AAA GAT ATT GGW ACT 3' and downstream COXI1549R-5' AGG CAT TTC TTC AAA NGT ATG ATA 3').

PCRs were carried out using the Thermal Cycler (USA), and the condition protocol used for these reactions consisted of an initial denaturation at $94^{\circ} \mathrm{C}$ for $10 \mathrm{~min}$, followed by 35 amplification cycles, denaturation at $94^{\circ} \mathrm{C}$ for $30 \mathrm{~s}$, annealing at $50^{\circ} \mathrm{C}$ for $30 \mathrm{~s}$, extension at $72^{\circ} \mathrm{C}$ for 2 min, and a final extension at $72^{\circ} \mathrm{C}$ for $10 \mathrm{~min}$. Electrophoresis was used to determine the DNA doubling results in the amplification process. The agarose gel composition was $1.5 \%$ of $80 \mathrm{~mL}$ of $1 \mathrm{x}$ TBE buffer solution or 1.2 grams of agarose, $8 \mathrm{~mL}$ of $10 \mathrm{x}$ TBE, and $72 \mathrm{~mL}$ of distilled water, then all were mixed in a $250 \mathrm{~mL}$ Erlenmeyer, homogenized, heated, and boiled. About $5 \mu \mathrm{L}$ of Florosafe was added to agarose before it was poured and solidified inside the electrophoresis chamber. TBE buffer $1 \mathrm{x}$ was added until the gel was submerged. Afterward, 10 $\mu \mathrm{L}$ of the amplified DNA sample was inserted into the well. Electrophoresis was run for 45 minutes at a voltage of 250 volts. Then agarose gel was taken and placed on a UV transilluminator. The products' sequences were determined and then used in making phylogenetic trees and analyzing genetic diversity.

\section{BLAST analysis}

Basic Local Alignment Search Tool (BLAST) was used to observe similarities in GenBank. This analysis was carried out using a web-based program, namely NCBI or National Center for Biotechnology (blast.ncbi.nih.nlm.gov) by entering the complete sample sequences which are the combined primary sequences of $\mathrm{F}$ and $\mathrm{R}$, into the BLAST.

\section{Phylogenetic trees}

Phylogenetic trees were prepared by using neighborjoining methods and bootstrap analysis (1,000 replicates) in the MEGA7 program.

\section{Genetic diversity}

Genetic diversity analysis was conducted by using the diversity of haplotypes. Hence, the alignment discovered included 28 sequences, namely 13 Gracilaria species from this study and 15 species of Gracilariaceae from GenBank. After multi-alignment, the Gracilaria species sequences were processed using the DNAsp 5.0 program to analyze intraspecific genetic diversity.

\section{RESULTS AND DISCUSSION}

\section{Morphological identification}

The red algal family Gracilariaceae covers approximately 230 species including Gracilaria, which are divided into 7 genera and also spread from temperate to tropical regions (Lyra et al. 2015; Guiry and Guiry 2020). The highest diversity of Gracilaria species is in the tropical area, specifically in Indo-Pacific and Western Antlantic region (Guiry and Guiry 2020). However, there is a lack of information and studies on the total number of Gracilaria species in Indonesia as a tropical country. In this study, a total of 13 species were collected from some sampling sites based on the preliminary morphological identification. These included 2 (Gracilaria coronopifolia and Gracilaria Salicornia) from Kondang Merak Beach, 2 (Gacilaria corticata and Gracilaria debilis) from Kukup Beach, 1 (Gracilaria debilis) from Menganti Beach, 3 (Gracilaria debilis, Gracilaria gigas, and Gracilariopsis longissimi) from Nusakambangan Beach, 3 (Gacilaria corticata, Gracilaria corticate, and Gracilariopsis longissimi) from Karapyak Beach, and 2 (Gracilaria gracilis and Gracilaria blodgettii) from Sayang Heulang Beach (Figure 2). Identification of the sample's morphological features such as thallus type, tip, and branching, etc. was carried out. It was observed that all samples showed similar branching type, either dichotomous or irregular (Figure 3). The Gracilaria species were observed based on morphological features including color, thallus habit, tips, segments, and texture, as well as holdfast, branching pattern, cell size gradation, cystocarp shape and size, nutritive filaments, pericarp, gonimoblast, spermatangial conceptacles, diameter, cell wall thickness $(\mu \mathrm{m})$, cortex and medulla (Table 1).

\section{Molecular identification}

After the previous process, molecular identification was performed based on sequencing analysis, and it has more advantages than morphological identification. The molecular identification of algal species has been successfully applied to various red seaweeds, including Gracilaria species (Yang et al. 2008; Yow et al. 2011; Gulbransen et al. 2012; Ng et al. 2017; Hifney et al. 2018; Song et al. 2019). The Gracilaria samples DNA concentration values ranged between 22.5-1137 ng / $\mu \mathrm{L}$, and DNA purity values ranged from 1.8-2.0. The DNA concentrations obtained were very diverse, but more than enough to be used in molecular analysis. The purity measurement aims to determine contaminants presence or absence, therefore when the value is below 1.8 and above 2.0 , then the DNA is contaminated with RNA and protein. The purity values obtained were still in a good range, hence the DNA was used for molecular analysis. 
There is a lack of information and study regarding the molecular identification and diversity of Indonesian seaweed including Gracilaria species. Most of such studies only focus on ecological aspect of seaweed, while the species identification was performed based on their morphological features. Some Indonesian seaweed studies conducted using RAPD method, determined the genetic diversity and productivity of $\mathrm{G}$. coronopifolia collected from Anyer Beach, Banten, Indonesia (Windarsih et al. 2019). However, RAPD utilization has some weaknesses, such as unreliable, because it gives a different product when repeated. In this study, to overcome the weaknesses, DNA barcoding method was employed using COX1 gene.
It has been previously shown that the COX1 gene is applicable in identifying red seaweed species (Yang et al. 2013; Yoon et al. 2014). This gene is a relatively short DNA portion and is easily amplified and sequenced with one pair of primers. The COX1 gene is one gene with a 1422 bp length out total of 53 genes with a 26,898 bp length contained in mitochondrial DNA (Lee et al. 2015). The amplification using the COX1 gene with COX143F and COX11549R primers from the thirteen Gracilaria spp. samples were successful, while DNA bands with 1422 bp size were produced. This condition showed the amplification was progressing well and had to be continued for the sequencing step.

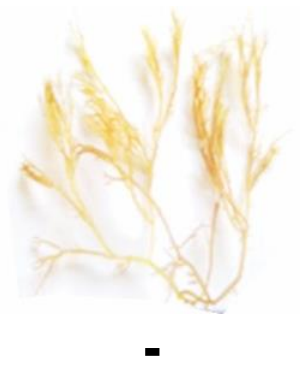

A

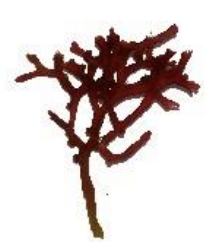

$\mathbf{E}$

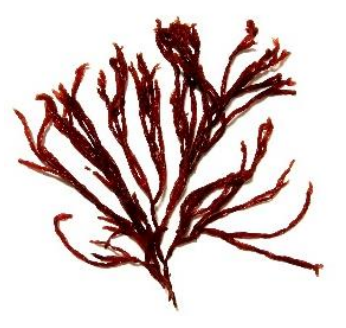

I

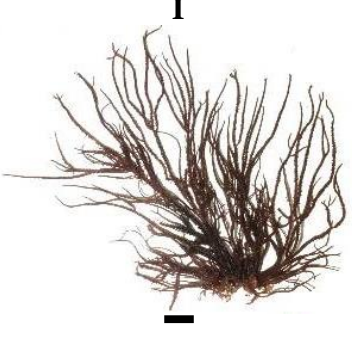

M

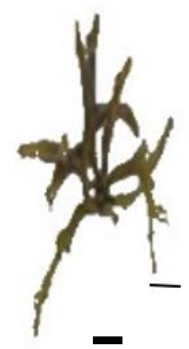

B
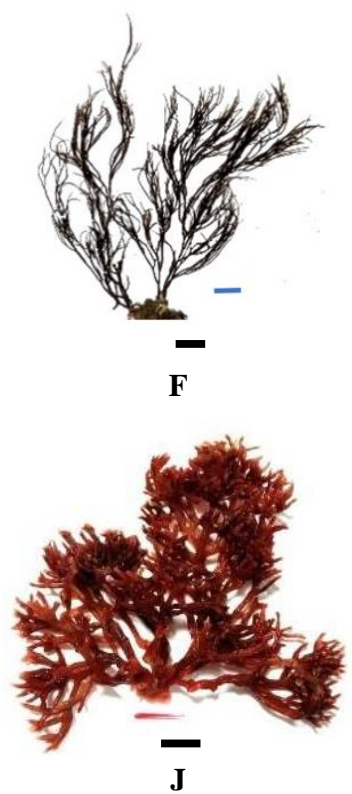

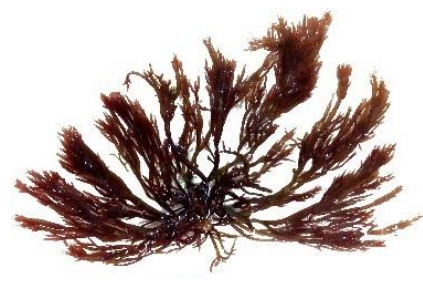

C

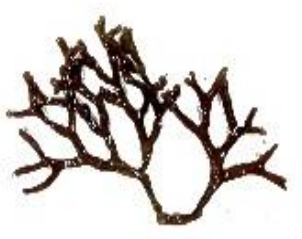

G

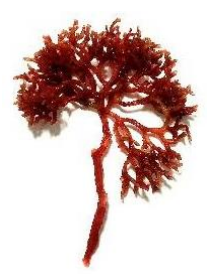

$\mathbf{K}$

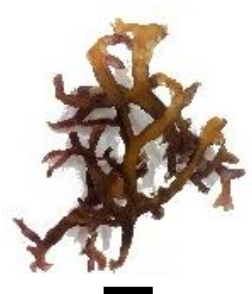

D

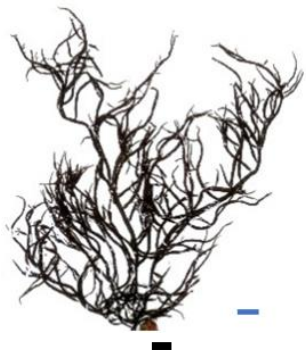

H

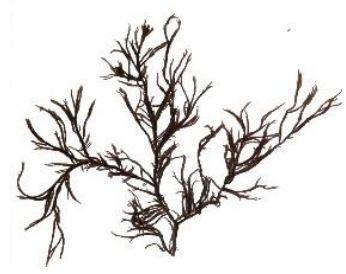

$\mathbf{L}$

Figure 2. Voucher species of Gracilaria spp. collected along the South Coast of Java Island, Indonesia. A. KM1: Gracilaria coronopifolia Kondang Merak; B. KM3: Gracilaria salicornia Kondang Merak; C. K1: Gracilaria corticata Kukup; D. K2: Gracilaria debilis Kukup; E. M1: Gracilaria debilis Menganti; F. NK1: Gracilaria gigas Nusakambangan; G. NK2: Gracilaria debilis Nusakambangan; H. NK3: Gracilaria coronopifolia Nusakambangan; I. F1: Gracilaria coronopifolia Karapyak; J. F4: Gracilaria corticata Karapyak; K. F6: Gracilaria corticata Karapyak; L. SH4: Gracilaria gracilis Sayang Heulang; M. SH6: Gracilaria blodgettii Sayang Heulang. Scale bars $=1 \mathrm{~cm}$ 
Table 1. Morphological characteristics of Gracilaria species obtained in this study

\begin{tabular}{|c|c|c|c|c|c|c|c|c|}
\hline $\begin{array}{l}\text { Morphological } \\
\text { characteristics }\end{array}$ & $\begin{array}{c}G . \\
\text { coronopifolia }\end{array}$ & G. salicornia & G. corticata & G. debilis & G. gigas & G. verrucosa & G. gracilis & G. blodgettii \\
\hline Color & $\begin{array}{l}\text { Yellowish to } \\
\text { brownish red }\end{array}$ & Dark green to greenish-brown & Purple-red & $\begin{array}{l}\text { Dark green to } \\
\text { blackish-red }\end{array}$ & $\begin{array}{l}\text { Dark green to } \\
\text { blackish-red }\end{array}$ & $\begin{array}{l}\text { Yellowish to } \\
\text { brownish-red }\end{array}$ & $\begin{array}{l}\text { Yellowish to brownish- } \\
\text { green }\end{array}$ & $\begin{array}{l}\text { Yellowish to brownish- } \\
\text { green }\end{array}$ \\
\hline Thallus habit & Not observed & Erect, $6.5 \mathrm{~cm}$ in length & $\begin{array}{l}\text { Erect, } 14 \mathrm{~cm} \text { in } \\
\text { length }\end{array}$ & $10 \mathrm{~cm}$ in length & $\begin{array}{l}10-15 \mathrm{~cm} \text { in } \\
\text { length }\end{array}$ & $\begin{array}{l}\text { Erect, } 30 \mathrm{~cm} \\
\text { in length }\end{array}$ & $\begin{array}{l}\text { Erect, } 20 \mathrm{~cm}(<1 \mathrm{~m} \text { depth })- \\
100 \mathrm{~cm}(>1 \mathrm{~m} \text { in depth) in } \\
\text { length }\end{array}$ & $200 \mathrm{~mm}$ in length \\
\hline Thallus tips & Pointed & Not observed & $\begin{array}{l}\text { Acute, sometimes } \\
\text { with proliferations }\end{array}$ & Not observed & & $\begin{array}{l}\text { Attenuated } \\
\text { and ultimate } \\
\text { small }\end{array}$ & Taper to an acute point & Attenuate \\
\hline $\begin{array}{l}\text { Thallus } \\
\text { segments }\end{array}$ & Absent & $\begin{array}{l}\text { Present, } 6 \text { articulated segments. } \\
\text { the segment base attenuated, the } \\
\text { apex obtuse, often dilated or } \\
\text { club-shaped }\end{array}$ & $\begin{array}{l}\text { Narrow segments, } \\
\text { segments usually } 2 \\
-4 \mathrm{~mm} \text { wide }\end{array}$ & Not observed & Not observed & Not observed & Absent & Absent \\
\hline $\begin{array}{l}\text { Texture of } \\
\text { thallus }\end{array}$ & Not observed & $\begin{array}{l}\text { Soft to slightly cartilaginous, } \\
\text { smooth }\end{array}$ & $\begin{array}{l}\text { Almost } \\
\text { cartilaginous }\end{array}$ & Not observed & $\begin{array}{l}\text { Soft to } \\
\text { slightly } \\
\text { cartilaginous, } \\
\text { smooth }\end{array}$ & Not observed & Cartilaginous & Not observed \\
\hline Holdfast & Discoid & Irregularly discoid & Discoid & Not observed & & Not observed & No holdfast & Discoid \\
\hline $\begin{array}{l}\text { Branching } \\
\text { pattern }\end{array}$ & Irregularly & $\begin{array}{l}\text { Irregularly subdichotomous to } \\
\text { trichotomous to alternate }\end{array}$ & $\begin{array}{l}\text { Mostly } \\
\text { dichotomous, up to } \\
\text { many orders }\end{array}$ & $\begin{array}{l}\text { Di-or sub- } \\
\text { dichotomously }\end{array}$ & $\begin{array}{l}\text { Di-or sub- } \\
\text { dichotomously }\end{array}$ & Irregularly & $\begin{array}{l}\text { Repeatedly and irregularly } \\
\text { branched, up to four orders }\end{array}$ & $\begin{array}{l}\text { Irregular, slightly } \\
\text { constricted at the base, } \\
\text { enlarged at the middle and } \\
\text { become attenuate at the tip }\end{array}$ \\
\hline $\begin{array}{l}\text { Cell size } \\
\text { gradation }\end{array}$ & Not observed & Not observed & Not observed & Not observed & Not observed & Not observed & Not observed & Not observed \\
\hline $\begin{array}{l}\text { Cystocarp shape } \\
\text { and size }\end{array}$ & Not observed & $\begin{array}{l}\text { Dome-shaped, with ostiole at } \\
\text { top }\end{array}$ & Not observed & $\begin{array}{l}\text { Dome-shaped, } \\
\text { scattered } \\
\text { over the mature } \\
\text { parts of the } \\
\text { thallus }\end{array}$ & Not observed & $\begin{array}{l}\text { Sub- } \\
\text { spherical, } \\
\text { elevated and } \\
\text { scattered } \\
\text { over the } \\
\text { thallus }\end{array}$ & $\begin{array}{l}\text { Cystocarps scattered } \\
\text { irregularly over the surface } \\
\text { of all branches; mature } \\
\text { cystocarps ostiolate, up to } \\
1 \mathrm{~mm} \text { high and } 1.2 \mathrm{~mm} \text { wide }\end{array}$ & Not observed \\
\hline $\begin{array}{l}\text { Nutritive } \\
\text { filaments }\end{array}$ & Not observed & Absent & Not observed & Not observed & Not observed & Not observed & Not observed & Not observed \\
\hline Pericarp & Not observed & Not observed & Not observed & Not observed & Not observed & Not observed & $\begin{array}{l}\text { Pericarp tissue up to } 220 \mu \mathrm{m} \\
\text { and } 13 \text { cell layers thick }\end{array}$ & Not observed \\
\hline
\end{tabular}




\begin{tabular}{|c|c|c|c|c|c|c|c|c|}
\hline Gonimoblast & Not observed & $\begin{array}{l}\text { Composed of loosely arranged } \\
\text { ovoid vacuolate cells bearing } \\
\text { clusters of carposporangia at } \\
\text { periphery in short branched } \\
\text { chains } \\
\text { Confined to unevenly }\end{array}$ & Not observed & Not observed & Not observed & Not observed & $\begin{array}{l}\text { Gonimoblast parenchyma } \\
\text { dense, central cells } \\
\text { up to } 20 \mu \mathrm{m} \text { wide }\end{array}$ & Not observed \\
\hline $\begin{array}{l}\text { Spermatangial } \\
\text { conceptacles }\end{array}$ & Not observed & $\begin{array}{l}\text { Confined to unevenly } \\
\text { distributed soral patches, } \\
\text { forming deep pits embedded in } \\
\text { the cortex, each with a narrow } \\
\text { opening to the outside and with } \\
\text { slender compressed cortical } \\
\text { cells attached to the outer } \\
\text { conceptacle wall }\end{array}$ & Not observed & Not observed & Not observed & Not observed & Not observed & Not observed \\
\hline Diameter & $1-2 \mathrm{~mm}$ & $3 \mathrm{~mm}$ & Not observed & Not observed & Not observed & Not observed & $0.8 \mathrm{~mm}$ & $1-2 \mathrm{~mm}$ \\
\hline $\begin{array}{l}\text { Wall thickness } \\
(\mu \mathrm{m})\end{array}$ & Not observed & Not observed & Not observed & Not observed & Not observed & Not observed & Not observed & Not observed \\
\hline Cortex & $\begin{array}{l}1-2 \text { layer of } \\
\text { small rounded } \\
\text { cortical cells }\end{array}$ & 1-2 layers & 1-2 layers & 1-2 layers & Not observed & & $\begin{array}{l}\text { Cortex of large branches } 1-3 \\
\text { cells thick, the cells darkly } \\
\text { staining, up to } 14 \mu \mathrm{m} \text { long } \\
\text { and } 10 \mu \mathrm{m} \text { wide. Subcortex } \\
1-2 \text { cells thick, cells lightly } \\
\text { staining, globose, up to } \\
80 \mu \mathrm{m} \text { long and } 40 \mu \mathrm{m} \text { wide }\end{array}$ & $\begin{array}{l}2-3 \text { layers of small } \\
\text { rounded cortical cells }\end{array}$ \\
\hline Medulla & $\begin{array}{l}\text { 3-4 layers of } \\
\text { parenchymato } \\
\text { us cells }\end{array}$ & Large central cells & Large central cells & $\begin{array}{l}\text { Large central } \\
\text { cells }\end{array}$ & Not observed & Not observed & $\begin{array}{l}\text { Medulla in this region up to } \\
7 \text { cells wide, the cells lightly } \\
\text { staining, polygonal to } \\
\text { spherical, increasing in size } \\
\text { towards the center, up to } \\
320 \mu \mathrm{m} \text { long and } 240 \mu \mathrm{m} \\
\text { wide }\end{array}$ & $\begin{array}{l}\text { 3-4 layers of } \\
\text { parenchymatous cells }\end{array}$ \\
\hline Habitat & $\begin{array}{l}\text { Attach to net } \\
\text { of cage } \\
\text { culture }\end{array}$ & $\begin{array}{l}\text { Lower mid littoral zone, rock } \\
\text { polls }\end{array}$ & $\begin{array}{l}\text { Lower mid littoral } \\
\text { zone and infra } \\
\text { littoral fringe }\end{array}$ & $\begin{array}{l}\text { Upper mid } \\
\text { littoral zone, } \\
\text { tide pools }\end{array}$ & $\begin{array}{l}\text { Lower mid } \\
\text { littoral zone, } \\
\text { tide pools }\end{array}$ & $\begin{array}{l}\text { Lower mid } \\
\text { littoral zone, } \\
\text { tide pools }\end{array}$ & Not observed & $\begin{array}{l}\text { Attached to root of } \\
\text { mangrove } \\
\text { Trees }\end{array}$ \\
\hline $\begin{array}{l}\text { Distribution in } \\
\text { this study }\end{array}$ & $\begin{array}{l}\text { Kondang } \\
\text { Merak Beach }\end{array}$ & Kondang Merak Beach & $\begin{array}{l}\text { Kukup Beach, } \\
\text { Karapyak Beach }\end{array}$ & $\begin{array}{l}\text { Kukup Beach, } \\
\text { Menganti } \\
\text { Beach, } \\
\text { Nusakambanga } \\
\text { n Beach }\end{array}$ & $\begin{array}{l}\text { Nusakambang } \\
\text { an Beach }\end{array}$ & $\begin{array}{l}\text { Nusakamban } \\
\text { gan Beach, } \\
\text { Karapyak } \\
\text { Beach }\end{array}$ & Sayang Heulang Beach & Sayang Heulang Beach \\
\hline
\end{tabular}




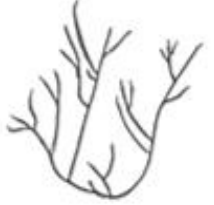

A

$\mathbf{E}$

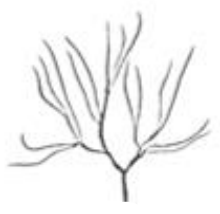

I

$\mathbf{F}$
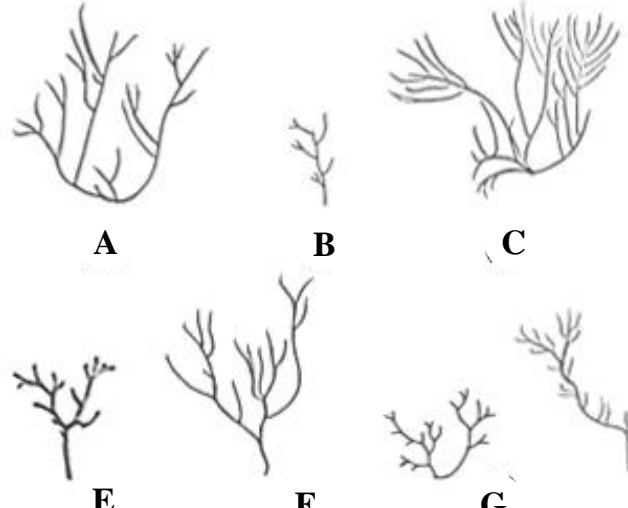

C

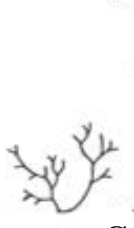

G
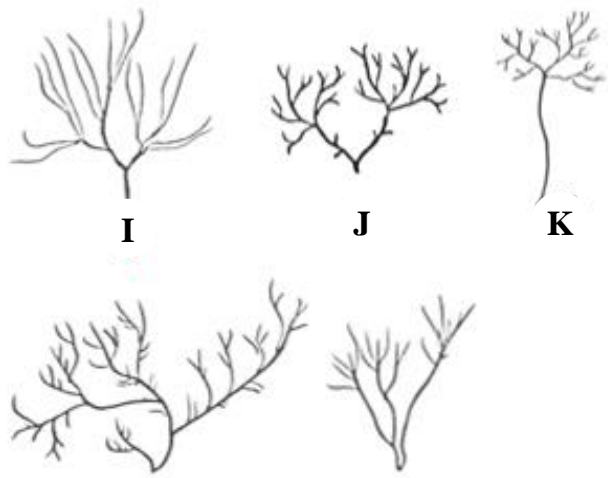

$\mathbf{L}$

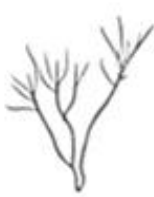

M

Figure 3. Branching type of Gracilaria spp. collected along the South Coast of Java Island, Indonesia. A. KM1: Gracilaria coronopifolia Kondang Merak; B. KM3: Gracilaria salicornia Kondang Merak; C. K1: Gracilaria corticata Kukup; D. K2: Gracilaria debilis Kukup; E. M1: Gracilaria debilis Menganti; F. NK1: Gracilaria gigas Nusakambangan; G. NK2: Gracilaria debilis Nusakambangan; H. NK3: Gracilaria coronopifolia Nusakambangan; I. F1: Gracilaria coronopifolia Karapyak; J. F4: Gracilaria corticata Karapyak; K. F6: Gracilaria corticata Karapyak; L. SH4: Gracilaria gracilis Sayang Heulang; M. SH6= Gracilaria blodgettii Sayang Heulang)

The blast analysis search results can be seen in Table 2, which showed the 13 samples consisted of 5 species, namely Gracilaria edulis, Gracilaria salicornia, Gracilaria textorii, Gracilaria firma and Hypnea sp. Romdoni et al., 2018 studied seaweed diversity based on their morphological features in two beaches along the Southern Part of Java Island, i.e. Drini and Kondang Merak. They found that Rhodophyta was the most abundant seaweed in both beaches, including G. salicornia and G. edulis also. This current study confirmed $G$. salicornia and G. edulis presence in Kondang Merak Beach through molecular identification using Cox 1 gene marker.

There are some differences between morphological and molecular identification, as shown in Table 3. Some studies showed Gracilaria species identification based on the morphological approach often led to misidentification. The misidentification of three Gracilaria species in Malaysia i.e. G. blodgettii, G. arcuata, and G. changii, was observed by Hassan et al. 2019. Molecular identification based on 672 bp CO1-5P gene sequence analysis indicated those three Gracilaria species need to be identified as one, namely Gracilaria blodgettii (Harvey 1853). Ng et al. (2017) validated two Gracilaria species, i.e. G. changii and $G$. firma.

Some study teams investigate the mitogenome sequence and complete plastid genome to obtain detailed molecular and phylogenetic information on Gracilaria species. Mitogenomes sequence is one of the fundamental approaches used to analyze the taxonomy and phylogeny of red algae (Boo et al. 2016). Sedanza et al. (2020) determined that the complete G. edulis mitogenome length was $25,708 \mathrm{bp}$ and this species clustered together with $G$. changii and G. salicornia. Wang et al. (2020) found $G$. chilensis plastid genome sequence was $185,640 \mathrm{bp}$ and it had a closer relationship with Gracilaria tenuistipitata var. liui in Gracilaria. Also, Liu et al. (2017) found the complete mitochondrial genome of G. chilensis was 26,897 bp and that G. chilensis, G. salicornia, and G. changii shared a closer relationship than G. vermiculophylla in the genus Gracilaria. Song et al. (2016) observe G. salicornia and found the mitogenome length was 25,915 bp containing 50 genes. Gracilaria species misidentification occurred due to high plasticity. since they have simple morphological features, lack of distinct morphological feature differentiation and complex heteromorphic reproduction cycle. Hence, identifying them solely based on morphological features is difficult (Zhao et al. 2013).

\section{Phylogenetic analysis}

Molecular identification using the COX1 gene can be further seen from the phylogenetic tree (Figure 4). To compare other data, 15 COX1 sequences were obtained from GenBank. The phylogenetic tree results showed each of the 13 sample and comparative species sequences assessed using the COX1 gene had different genetic distances, both intraspecific and interspecific. Overall, the intraspecific genetic distance ranged from $0-1.0 \%$, while the interspecific genetic distance of Gracilaria spp. ranged from 10.4-14.7\%. Also, the interspecific genetic distance of the genus Gracilaria and Hypnea ranged between 16.3$20.5 \%$. This value is comparable to the study of $G$. vermiculophylla presence in the western Atlantic region where the intraspecific genetic distance of Gracilaria species ranged between $0.0 \%$ and $1.73 \%$ (Gulbransen et al. 2012).

COX1 genes utilization for analysis of genetic diversity, both intraspecific (genetic variation within species) and interspecific (variations between species) has produced good results. This can be seen from the distance or genetic variation both intraspecifically and interspecifically. The intraspecific diversity of $G$. salicornia was $0-1 \%$, G. edulis was 0 to $0.6 \%$, and G. firma was $0-2 \%$, while that of $G$. textorii was $0-10.6 \%$. According to Yang and Kim 2015, intraspecific diversity has a genetic distance ranging from $0-2.6 \%$. A very high intraspecific genetic distance in the COX1 gene causes errors in the identification process (Robba et al. 2006). 
Table 2. The BLAST results obtained from the Cox 1 gene partial sequences for each sample from six different beaches in Indonesia were compared with the results of morphological identification results

\begin{tabular}{|c|c|c|c|c|c|}
\hline Sampling location & GPS coordinate & Code & Genbank strain & No. accession & Similarity \\
\hline \multirow[t]{2}{*}{ Kondang Merak } & $8^{\circ} 23^{\prime} 52.44 " \mathrm{~S}$ & KM1 & Gracilaria edulis & KY995645 & $99,68 \%$ \\
\hline & $112^{\circ} 31^{\prime} 25.62^{\prime \prime T}$ & KM3 & Gracilaria salicornia & KF831096 & $100 \%$ \\
\hline \multirow[t]{2}{*}{ Kukup } & $8^{\circ} 06^{\prime} 48.68^{\prime \prime} \mathrm{S}$ & K1 & Gracilaria edulis & KY995645 & $99,67 \%$ \\
\hline & $110^{\circ} 34^{\prime} 44.41^{\prime \prime} \mathrm{T}$ & $\mathrm{K} 2$ & Gracilaria salicornia & KF831096 & $100 \%$ \\
\hline \multirow[t]{2}{*}{ Menganti } & $7^{\circ} 45^{\prime} 32.18^{\prime \prime S}$ & M1 & Gracilaria textorii & NC_037892 & $90,2 \%$ \\
\hline & $109^{\circ} 25^{\prime} 19.41^{\prime \prime T}$ & & & & \\
\hline \multirow{3}{*}{ Nusakambangan } & $7^{\circ} 45^{\prime} 15.29 " \mathrm{~S}$ & NK1 & Gracilaria edulis & KY995645 & $99,68 \%$ \\
\hline & $109^{\circ} 01^{\prime} 04.68^{\prime \prime T}$ & NK2 & Gracilaria salicornia & KF831096 & $100 \%$ \\
\hline & & NK3 & Gracilaria firma & KY315283 & $100 \%$ \\
\hline \multirow[t]{3}{*}{ Karapyak } & $7^{\circ} 42^{\prime} 9.86 " \mathrm{~S}$ & $\mathrm{~F} 1$ & Gracilaria edulis & NC_037889 & $99,42 \%$ \\
\hline & $108^{\circ} 45^{\prime} 38.28^{\prime \prime} \mathrm{T}$ & F4 & Gracilaria edulis & KY995645 & $99,42 \%$ \\
\hline & & F6 & Gracilaria edulis & KY995645 & $99,67 \%$ \\
\hline \multirow[t]{2}{*}{ Sayang Heulang } & $7^{\circ} 38^{\prime} 16.34 " \mathrm{~S}$ & SH4 & Hypnea sp. & EU240816 & $90,27 \%$ \\
\hline & $107^{\circ} 41^{\prime} 50.30^{\prime \prime} \mathrm{T}$ & SH6 & Hypnea sp. & EU240816.1 & $90,27 \%$ \\
\hline
\end{tabular}

Table 3. Comparison of Gracilaria species morphological and molecular identification

\begin{tabular}{|c|c|c|c|c|}
\hline Sampling location & GPS coordinate & Code & Morphological identification & Molecular identification \\
\hline Kondang Merak & $\begin{array}{l}8^{\circ} 23^{\prime} 52.44 " \mathrm{~S} \\
112^{\circ} 31^{\prime} 25.62^{\prime \prime} \mathrm{T}\end{array}$ & $\begin{array}{l}\text { KM1 } \\
\text { KM3 }\end{array}$ & $\begin{array}{l}\text { Gracilaria coronopifolia } \\
\text { Gracilaria salicornia }\end{array}$ & $\begin{array}{l}\text { Gracilaria edulis } \\
\text { Gracilaria salicornia }\end{array}$ \\
\hline Kukup & $\begin{array}{l}8^{\circ} 06^{\prime} 48.68^{\prime \prime} \mathrm{S} \\
110^{\circ} 34^{\prime} 44.41^{\prime \prime T}\end{array}$ & $\begin{array}{l}\mathrm{K} 1 \\
\mathrm{~K} 2\end{array}$ & $\begin{array}{l}\text { Gracilaria corticata } \\
\text { Gracilaria debilis }\end{array}$ & $\begin{array}{l}\text { Gracilaria edulis } \\
\text { Gracilaria salicornia }\end{array}$ \\
\hline Menganti & $\begin{array}{l}7^{\circ} 45^{\prime} 32.18 " \mathrm{~S} \\
109^{\circ} 25^{\prime} 19.41 " \mathrm{~T}\end{array}$ & M1 & Gracilaria debilis & Gracilaria textorii \\
\hline Nusakambangan & $\begin{array}{l}7^{\circ} 45^{\prime} 15.29 " \mathrm{~S} \\
109^{\circ} 01^{\prime} 04.68^{\prime \prime} \mathrm{T}\end{array}$ & $\begin{array}{l}\text { NK1 } \\
\text { NK2 } \\
\text { NK3 }\end{array}$ & $\begin{array}{l}\text { Gracilaria gigas } \\
\text { Gracilaria debilis } \\
\text { Gracilaria verrucose }\end{array}$ & $\begin{array}{l}\text { Gracilaria edulis } \\
\text { Gracilaria salicornia } \\
\text { Gracilaria firma }\end{array}$ \\
\hline Karapyak & $\begin{array}{l}7^{\circ} 42^{\prime} 9.86^{\prime \prime S} \\
108^{\circ} 45^{\prime} 38.28^{\prime \prime T}\end{array}$ & $\begin{array}{l}\text { F1 } \\
\text { F4 } \\
\text { F6 }\end{array}$ & $\begin{array}{l}\text { Gracilaria verrucosa } \\
\text { Gracilaria corticata } \\
\text { Gracilaria corticata }\end{array}$ & $\begin{array}{l}\text { Gracilaria edulis } \\
\text { Gracilaria edulis } \\
\text { Gracilaria edulis }\end{array}$ \\
\hline Sayang Heulang & $\begin{array}{l}7^{\circ} 38^{\prime} 16.34 " \mathrm{~S} \\
107^{\circ} 41^{\prime} 50.30^{\prime \prime} \mathrm{T}\end{array}$ & $\begin{array}{l}\text { SH4 } \\
\text { SH6 }\end{array}$ & $\begin{array}{l}\text { Gracilaria gracilis } \\
\text { Gracilaria blodgettii }\end{array}$ & $\begin{array}{l}\text { Hypnea sp. } \\
\text { Hypnea sp. }\end{array}$ \\
\hline
\end{tabular}

However, interspecific diversity between G. salicornia and G. firma ranged from 13.9-14.7\%, G. salicornia and $G$. edulis was $12.4-12.9 \%$, G. firma and G. edulis was 13.5$14.1 \%$, Gracilaria textorii and G. salicornia was 11.8$13.9 \%$, G. textorii and G. edulis was $12.9-13.9 \%$, while $G$. textorii and G. firma was 10.6 to $12.9 \%$. Yang and Kim, 2015 conducted a molecular analysis using mitochondrial COX1 and plastid rbcL genes for identifying the Gracilaria species obtained from the Asia-Pacific region. The range of intra-and inter-specific divergence for COX1 gene was 0-2.6 \% and 2.8-15.7\%, respectively. RbcL data showed that the interspecific divergences ranged from 1.1 to 14.8 $\%$ and divided into two large clades, such as Gracilaria sensu lato and Gracilariopsis (Yang and Kim 2015).

Low nucleotide variations in molecular markers within and between species are prerequisites for coding (Saunders 2005; Robba et al. 2006). 


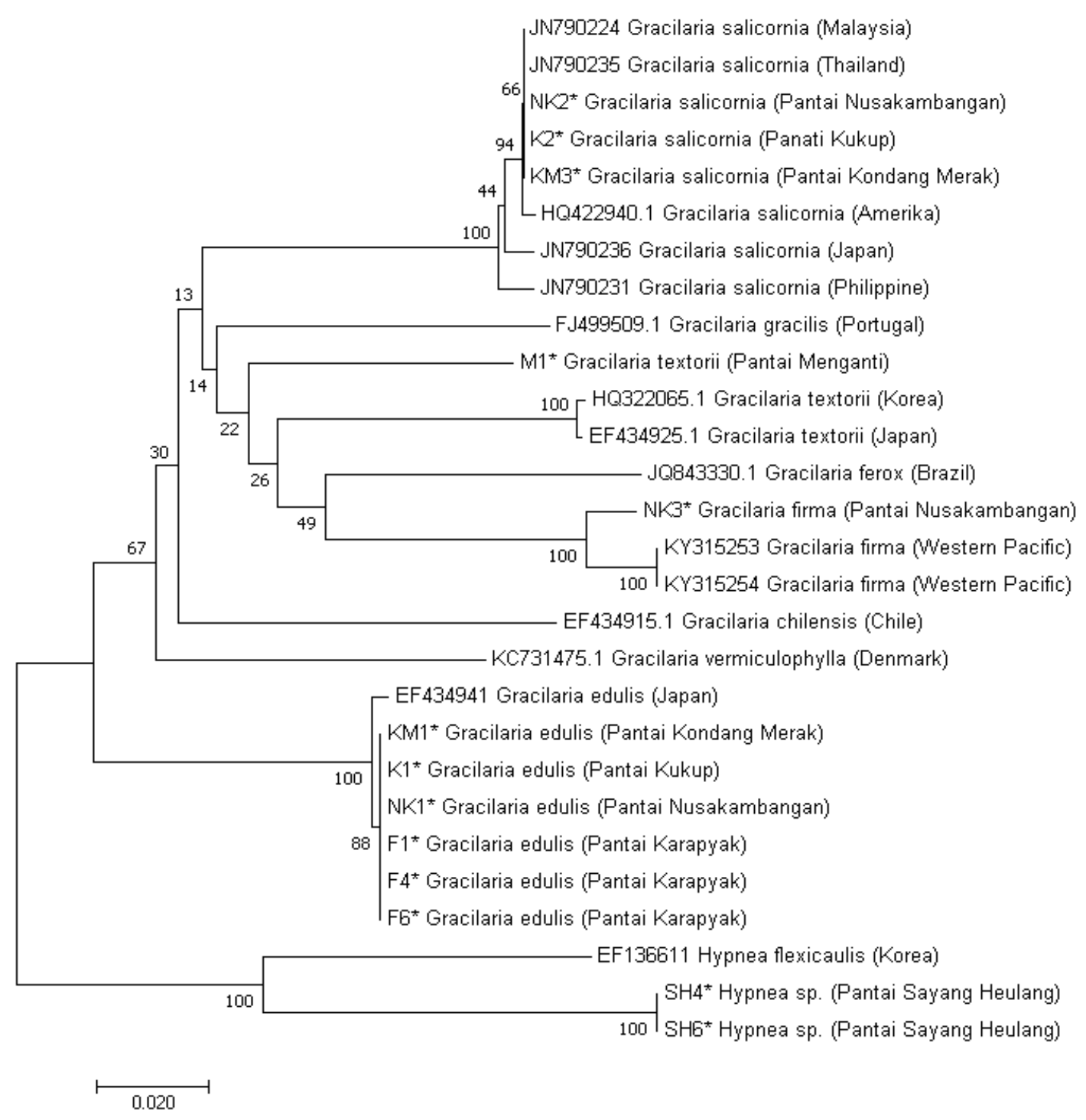

Figure 4. Phylogenetic tree of Gracilaria spp. collected along the South Coast of Java Island, Indonesia

Molecular identification of the seven samples obtained from the six beaches showed one Hypnea sp. and four Gracilaria spp. Furthermore, the Hypnea sp. consisted of two samples from Menganti and Pantai Sayang Heulang Beach. Also, the Gracilaria spp. consisted of 12 samples, namely G. salicornia (from Kondang Merak, Kukup, and Nusakambangan Beach), G. edulis (from Kondang Merak, Kukup, Karapyak, and Nusakambangan Beach), G. firma (from Nusakambangan Beach) and G. textorii (from Karapyak and Menganti Beach). Moreover, genetic diversity analysis was performed by observing haplotype diversity (Hd). Based on the molecular identification results, Gracilaria spp, intraspecifically, consisted of three species namely $G$. edulis, $G$. salicornia and $G$. textorii. But, interspecifically, it consists of four species namely $G$. salicornia, G. edulis, G. firma and G. textorii. Intraspecific genetic diversity analysis of Gracilaria spp was carried out using DNAsp 5.0 application. This showed G. edulis and $G$. salicornia obtained from the beaches of Kondang
Merak, Kukup, Nusakambangan, and Karapyak had a diversity value of 0.53 and 0.67 , respectively, and both belonged to the moderate diversity category, while the intraspecific diversity of $G$. textorii obtained from Menganti and Karapyak Beach had a value of 0 or no diversity. Valtueña et al. 2014 stated low genetic diversity is caused by inbreeding or an inbreeding within a population.

The results of genetic diversity analysis conducted using the COX1 gene showed the intraspecific diversity of G. edulis obtained from the beaches of Kondang Merak, Kukup, Nusakambangan, and Karapyak was included in the moderate diversity category. Also, the intraspecific diversity of $G$. salicornia obtained from the beaches of Kondang Mera, Kukup, and Nusakambangan was included in the moderate diversity category, while the intraspecific diversity of $G$. textorii from Menganti and Karapyak Beach had no diversity. Further study is recommended to be conducted on genetic variability of seaweed Gracilaria 
spp. obtained from Kondang Merak, Nusakambangan, and Sayang Heulang Beach using genes other than the COX1. Among the 230 Gracilaria species found globally, only 150 have been described and identified (Lyra, 2015; Guiry and Guiry 2020). In Indonesia, few Gracilaria species have been studied and identified, hence there is a need for more exploration and identification efforts. Species molecular identification is an important step that we must conduct before exploring and utilizing the Gracilaria species. By identifying the Gracilaria species we can do more explorations and develop Gracilaria species to become high-value products.

\section{ACKNOWLEDGEMENTS}

The authors are grateful for the support provided by the Applied Leading Research (Riset Unggulan Terapan) 2019 grant under No. 272/UN23/14/PN/2019, from BLU, Jenderal Soedirman University, Indonesia.

\section{REFERENCES}

Bixler HJ, Porse H. 2011. A decade of change in the seaweed hydrocolloids industry. J Appl Phycol 23: 321-335. DOI: 10.1007/s10811-010-9529-3.

Boo GH, Hughey JR, Miller KA, Boo SM. 2016. Mitogenomes from type specimens, a genotyping tool for morphologically simple species: Ten genomes of agar-producing red algae. Sci Rep 6: 35337. DOI: 10.1038/srep35337.

de Almeida CLF, Falcão H de S, de M Lima GR, de A Montenegro C, Lira NS, de Athayde-Filho PF, Rodrigues LC, de Souza MFV, Barbosa-Filho JM, Batista LM. 2011. Bioactivities from marine algae of the genus Gracilaria. Intl J Mol Sci 12: 4550-4573. DOI: 10.3390/ijms 12074550 .

FAO. 2020. The State of World Fisheries and Aquaculture 2020. Food and Agriculture Organization of United Nations, Rome.

Geraldino PJL, Yang E-C, Bu S-M. 2006. Morphology and molecular phylogeny of Hypnea flexicaulis (Gigartinales, Rhodophyta) from Korea. Algae 21: 417-423. DOI: 10.4490/algae.2006.21.4.417.

Gulbransen DJ, Mcglathery KJ, Marklund M, Norris JN, Gurgel CFD 2012. Gracilaria vermiculophylla (Rhodophyta, Gracilariales) in the Virginia Coastal Bays, USA: COX1 analysis reveals high genetic richness of an introduced macroalga. J Phycol 48: 1278-1283. DOI: 10.1111/j.1529-8817.2012.01218.x.

Guiry MD, Guiry GM. 2020. AlgaeBase, Worldwide electronic publication, National University of Ireland, Galway.

Hassan R, Othman MNA, Harith MN, Md Sah ASR. 2019. Morphological diversity of Gracilaria blodgettii Harvey 1853 (Gracilariaceae, Rhodophyta) from Sarawak, Malaysian Borneo. Scientifica (Cairo) 2019: 3430968. DOI: 10.1155/2019/3430968

Heo J-S, Park S-K, Yoo H-I, Song N, Kim B-Y, Choi H-G. 2011 Macroalgal community structure on the Rocky Shores of Ongdo, Jusamdo, and Woejodo Islands of the Yellow Sea, Korea. Fish Aquat Sci 14: 389-397. DOI: 10.5657/FAS.2011.0389.

Hifney AF, Fawzy MA, Abdel-Gawad KM, Gomaa M. 2018. Upgrading the antioxidant properties of fucoidan and alginate from Cystoseira trinodis by fungal fermentation or enzymatic pretreatment of the seaweed biomass. Food Chem 269: 387-395. DOI: 10.1016/j.foodchem.2018.07.026.

Hutomo M, Moosa MK. 2005. Indonesian marine and coastal biodiversity: Present status. Indian J Mar Sci 34: 88-97.

Kadi A. 2004. Potensi rumput laut dibeberapa perairan pantai Indonesia. Oseana 29: 25-36. [Indonesian]

Kim MS, Yang MY, Cho GY. 2010. Applying DNA barcoding to Korean Gracilariaceae (Rhodophyta). Cryptogam Algol 31: 387-401.
Kongkittayapun N, Chirapart A. 2011. Morphometric and molecular analysis of Gracilaria salicornia and its adelphoparasite in Thailand. ScienceAsia 37: 6-16. DOI: 10.2306/scienceasia1513-1874.2011.37.006.

Lee JM, Boo SM, Mansilla A, Yoon HS. 2015. Unique repeat and plasmid sequences in the mitochondrial genome of Gracilaria chilensis (Gracilariales, Rhodophyta). Phycologia 54: 20-23. DOI: 10.2216/PH14-97.1.

Liu N, Wang G, Li Y, Zhang, L Meinita MDN, Chen W, Liu T, Chi S. 2017. The complete mitochondrial genome of the economic red alga, Gracilaria chilensis. Mitochondrial DNA Part B 2 (2): 716-717. DOI: 10.1080/23802359.2017.1390416.

Lyra G de M, Costa E da S, de Jesus PB, de Matos JCG, Caires TA, Oliveira MC, Oliveira EC, Xi Z, de C Nunes JM, Davis CC. 2015. Phylogeny of Gracilaria (Rhodophyta) evidence from plastid and mitochondrial nucleotide sequences. J Phycol 51: 356-366. DOI: 10.1111/jpy.12281.

Meinita MDN, Marhaeni B, Hong YK, Jeong GT. 2017. Enzymatic saccharification of agar waste from Gracilaria verrucosa and Gelidium latifolium for bioethanol production. J Appl Phycol 29: 3201-3209. DOI: 10.1007/s10811-017-1205-4.

Meinita MDN, Marhaeni B, Oktaviani DF, Jeong G-T, Hong Y-K. 2018. Comparison of bioethanol production from cultivated versus wild Gracilaria verrucosa and Gracilaria gigas. J Appl Phycol 30: 143147. DOI: 10.1007/s10811-017-1297-x.

Nesbitt M, McBurney RPH, Broin M, Beentje HJ. 2010. Linking biodiversity, food and nutrition: The importance of plant identification and nomenclature. J Food Compos Anal 23: 486-498. DOI: 10.1016/j.jfca.2009.03.001.

Ng PK, Lin SM, Lim PE, Hurtado AQ, Phang S-M, Yow Y-Y, Sun Z. 2017. Genetic and morphological analyses of Gracilaria firma and $G$. changii (Gracilariaceae, Rhodophyta), the commercially important agarophytes in western Pacific. PLoS One 12 (7): e0182176. DOI: 10.1371/journal.pone.0182176.

Pambudi LT, Dyah M, Meinita N, Ariyati RW. 2010. Seaweed cultivation in Indonesia: Recent status. J Mar Biosci Biotechnol 4: 6-10.

Porse H, Rudolph B. 2017. The seaweed hydrocolloid industry: 2016 updates, requirements, and outlook. J Appl Phycol 29: 2187-2200 DOI: $10.1007 / \mathrm{s} 10811-017-1144-0$.

Robba L, Russell SJ, Barker GL, Brodie J. 2006. Assessing the use of the mitochondrial cox1 marker for use in DNA barcoding of red algae (Rhodophyta). Am J Bot 93: 1101-1108. DOI: 10.3732/ajb.93.8.1101.

Romdoni TA, Ristiani A, Meinita MDN, Marhaeni B, Setijanto. 2018. Seaweed species composition, abundance and diversity in Drini and Kondang merak beach, Java. E3S Web Conf 47: 1-8. DOI: $10.1051 / \mathrm{e} 3$ sconf/20184703006.

Saunders GW. 2005. Applying DNA barcoding to red macroalgae: A preliminary appraisal holds promise for future applications. Philos Trans R Soc B Biol Sci 360: 1879-1888. DOI: 10.1098/rstb.2005.1719.

Sedanza MGC, Meinita MDN, Tang X, Chen W, Yin H, Liu C, Jin Y, Chi S, Li Y, Liu T. 2020. Complete sequence of mitochondrial DNA of Gracilaria edulis (Rhodophyta). Mitochondrial DNA Part B 5: 11281129. DOI: 10.1080/23802359.2017.1422413.

Sherwood AR, Kurihara A, Conklin KY. 2011. Molecular diversity of Amansieae (Ceramiales, Rhodophyta) from the Hawaiian Islands: A multi-marker assessment reveals high diversity within Amansia glomerata. Phycol Res 59: 16-23. DOI: 10.1111/j.14401835.2010.00591.x.

Song SL, Yong H Sen, Lim PE, Ng P-K, Phang S-M. 2016. Complete mitochondrial genome, genetic diversity and molecular phylogeny of Gracilaria salicornia (Rhodophyta: Gracilariaceae). Phycologia 55: 371-377. DOI: 10.2216/15-128.1.

Song XH, Hu ZM, Sun ZM, Draisma SGA, Fresia P, Duan D-L. 2019. Species diversity and distribution of the genus Colpomenia (Scytosiphonaceae, Phaeophyceae) along the coast of China. Algae 34: 217-228. DOI: 10.4490/algae.2019.34.7.22.

Torres P, Santos JP, Chow F, dos Santos DYAC. 2019. A comprehensive review of traditional uses, bioactivity potential, and chemical diversity of the genus Gracilaria (Gracilariales, Rhodophyta). Algal Res 37: 288-306. DOI: 10.1016/j.algal.2018.12.009.

Valtueña FJ, López J, Ortega-Olivencia A, Rodríguez-riaño T, González M. 2014. Contrasting inbreeding depression in early and late stages of the life cycle of a Mediterranean shrub, Anagyris foetida (Leguminosae). Turk J Bot 38: 334-346. DOI: 10.3906/bot-1303-28.

Wang G, Liu N, Li Y, Zhang L, Meinita MDN, Chen W, Liu T, Chi S. 2020. The complete plastid genome and phylogenetic analysis of 
Gracilaria chilensis. Mitochondrial DNA Part B Resour 5: 12821283. DOI: $10.1080 / 23802359.2018 .1431070$.

Windarsih G, Utami DW, Yuriyah S. 2019. Genetic diversity and productivity of Gracilaria coronopifolia as alternative for food resource based on RAPD marker. Biodiversitas 20: 3758-3765. DOI: 10.13057/biodiv/d201239.

Yang EC, Kim MS, Geraldino PJL, Sahoo D, Shin J-A, Boo SM. 2008 Mitochondrial cox1 and plastid rbcL genes of Gracilaria vermiculophylla (Gracilariaceae, Rhodophyta). J Appl Phycol 20: 161-168. DOI: 10.1007/s10811-007-9201-8.

Yang MY, Geraldino PJL, Kim MS. 2013. DNA barcode assessment of Gracilaria salicornia (Gracilariaceae, Rhodophyta) from Southeast Asia. Bot Stud 54 (1): 27. DOI: 10.1186/1999-3110-54-27.

Yang MY, Kim MS. 2015. Molecular analyses for identification of the Gracilariaceae (Rhodophyta) from the Asia-Pacific region. Genes Genom 37: 775-787. DOI: 10.1007/s13258-015-0306-1.
Yoon KJ, Kim KM, Boo GH, Miller KA, Boo SM. 2014. Mitochondrial cox 1 and cob sequence diversities in Gelidium vagum (Gelidiales, Rhodophyta) in Korea. Algae 29: 15-25. DOI: 10.4490/algae.2014.29.1.015.

Yow YY, Lim PE, Phang SM. 2011. Genetic diversity of Gracilaria changii (Gracilariaceae, Rhodophyta) from west coast, Peninsular Malaysia based on mitochondrial cox1 gene analysis. J Appl Phycol 23: 219-226. DOI: 10.1007/s10811-010-9535-5.

Zhao X, Pang S, Shan T, Liu F. 2013. Applications of three DNA barcodes in assorting intertidal red macroalgal flora in Qingdao, China. J Ocean Univ China 12: 139-145. DOI: 10.1007/s11802-0132052-9. 